\title{
Vegetation Regrowth Following Wildfires in the Santa Cruz Mountains of Northern California Monitored Using Landsat Satellite Image Analysis
}

\author{
Christopher S. Potter \\ NASA Ames Research Center, Moffett Field, CA, USA \\ Email: chris.potter@nasa.gov \\ Received 15 January 2016; accepted 2 February 2016; published 5 February 2016 \\ Copyright (C) 2016 by author and Scientific Research Publishing Inc. \\ This work is licensed under the Creative Commons Attribution International License (CC BY). \\ http://creativecommons.org/licenses/by/4.0/ \\ (c) (i) Open Access
}

\begin{abstract}
The Santa Cruz Mountain range in northern California is a coastal landscape with a history of extensive forest logging and frequent large wildfires that have recently destroyed numerous residential structures at the wildland interface. Results from Landsat satellite image time-series analysis since 1984 of the study area within the Los Gatos Creek and Corralitos Creek watersheds showed that none of the severe drought periods since the 1980 s have notably inhibited rapid tree and shrub regrowth rates on steep hill slopes burned recently by the 1985 Lexington Fire and the 2008 Summit Fire. In high burn severity areas of both fires, post-fire vegetation types showed a marked increase in shrub cover, mainly at the expense of evergreen tree cover. Most of these low $(<3 \mathrm{~m})$, dense stands of evergreen woody species have regenerated in as little as five years from bare charred ground. A combination of Landsat and Laser Altimeter (GLAS) satellite sensor data revealed that exposed south-facing slopes are presently supporting 200 to $240 \mathrm{Mg} \cdot \mathrm{ha}^{-1} \mathrm{of}$ standing woody biomass on the burned areas. This study is the first of its kind to utilize a full 30 -year record of Landsat vegetation index data to monitor tree and shrub regrowth after stand-replacing wildfires in California.
\end{abstract}

\section{Keywords}

Landsat, California, Santa Cruz Mountains, Forest, Shrub, Wildfire, Drought, NDVI

\section{Introduction}

Wildfires over the past 30 years have had notable impacts on forest cover of the Santa Cruz Mountains in northern

How to cite this paper: Potter, C. S. (2016). Vegetation Regrowth Following Wildfires in the Santa Cruz Mountains of Northern California Monitored Using Landsat Satellite Image Analysis. Open Journal of Forestry, 6, 82-93. 
California. For example, the Summit and Lockheed Fires of 2008 and 2009 together burned a total of 5888 ha over just two years (SEAT, 2008; CDFFP, 2009), which is equivalent to nearly $5 \%$ of all evergreen forest cover in the Santa Cruz Mountains area (Potter, 2015). The risk of wildfire damage to cities and towns on the margins of the Santa Cruz Mountains is a major concern to local governments (County of Santa Cruz, 2013). A high percentage of homes in the three main counties of the region are located on the Wildland Urban Interface (WUI), which includes vacant lots, highway medians, rural roadways, parks, golf courses, and rural residential properties (Headwaters Economics, 2008). With evidence mounting that the fire season in California is starting sooner and lasting longer (Westerling et al., 2006; Dennison et al., 2014), local planners and emergency responders may be forced to deal with more wildfires like those from the past decade in the Santa Cruz Mountains. For effective management planning and decision-making, this information needs to be based on the most detailed spatial data available at the small drainage basin scale (Flint \& Flint, 2012).

The Landsat normalized difference vegetation index (NDVI) has been shown to be a reliable metric to monitor large-scale change in green vegetation cover and forest disturbance in remote mountainous areas (Collins \& Woodcock, 1996; Rogan \& Franklin, 2001; Rogan et al., 2003; Fischer et al., 2004; Epting \& Verbyla, 2005; Cuevas-Gonzalez et al., 2009; Casady \& Marsh, 2010; Gitas et al., 2012). Results from Landsat image studies have shown that canopy green leaf cover typically increases rapidly over the first five years following a standreplacing disturbance, doubling in value by about 10 years after the disturbance, and then leveling off to approach pre-disturbance (mature) stand values by about 25 - 30 years after the disturbance event (Potter, 2014a). In addition, annual vegetation evapotranspiration (ET) flux in montane and sub-alpine communities of the western U. S. has been closely correlated with satellite NDVI (Goulden \& Bales, 2014).

A verified NDVI-to-leaf area index (LAI) predictive relationship developed by Baret et al. (1989) has been used to convert NDVI into LAI values by McMichael et al. (2004) using Landsat Thematic Mapper (TM) and Enhanced Thematic Mapper (ETM) images for chaparral shrub cover in southern California, and LAI estimates were plotted against stand age locations in a 80-year chronosequence of shrub stands. Results indicated that chaparral LAI recovers rapidly during the first 15 years after fire, and then remains stable for decades between fires.

In the present study, Landsat satellite imagery at 30-m ground resolution was analyzed for two large wildfires, which occurred in 1985 and 2008 in the Santa Cruz Mountains, to determine if vegetation regrowth patterns were similar across the two adjacent burned areas. The study design controlled for variations in vegetation cover types, elevation, slope, and aspect gradients.

The main questions addressed in this study of long-term changes in Landsat NDVI for these two wildfires in close proximity to one another were:

- Has there been a detectable change in canopy cover regrowth in different burn severity classes since the two fire events?

- Have the variations in precipitation over the past 30 years had significant impacts on post-fire vegetation regrowth rates in these two burned areas?

\section{Study Area Description}

The Santa Cruz Mountain range covers an estimated area of $3170 \mathrm{~km}^{2}$ that extends from sea level at the Pacific coast to $1155 \mathrm{~m}$ at the top of Loma Prieta peak (Thomas, 1961) (Figure 1). The range forms a ridge along the San Francisco Peninsula, separating the Pacific Ocean from the San Francisco Bay and the Santa Clara Valley, continuing south, bordering the Monterey Bay and ending at the northern Salinas Valley. The mountain area falls mainly within three California counties, San Mateo, Santa Cruz and Santa Clara.

Vegetation cover in the Santa Cruz Mountains (Table 1) is predominantly secondary-growth temperate forest (Han et al., 2012; Bakker, 1984), composed of coast redwood (Sequoia sempervirens), Douglas-fir (Pseudotsuga menziesii), knobcone pine (Pinus attenuata), coast live oak (Quercus agrifolia), Pacific madrone (Arbutus menziesii), manzanita (Arctostaphylos andersonii), and California bay laurel (Umbellularia californica) (Thomas, 1961). Common shrub species found in the study area are blue blossom (Ceanothus thyrsiflorus), coyote brush (Baccharis pilularis), chamise (Adenostoma fasciculatum), Monkey-flower (Mimulus sp.) and Golden-bush (Ericameria arborescens).

Starting in the 1850s, the majority of old-growth forest stands in the Santa Cruz Mountains were heavily logged to meet the demand for lumber to build new cities in the San Francisco Bay area (Stephens \& Fry, 2005). 


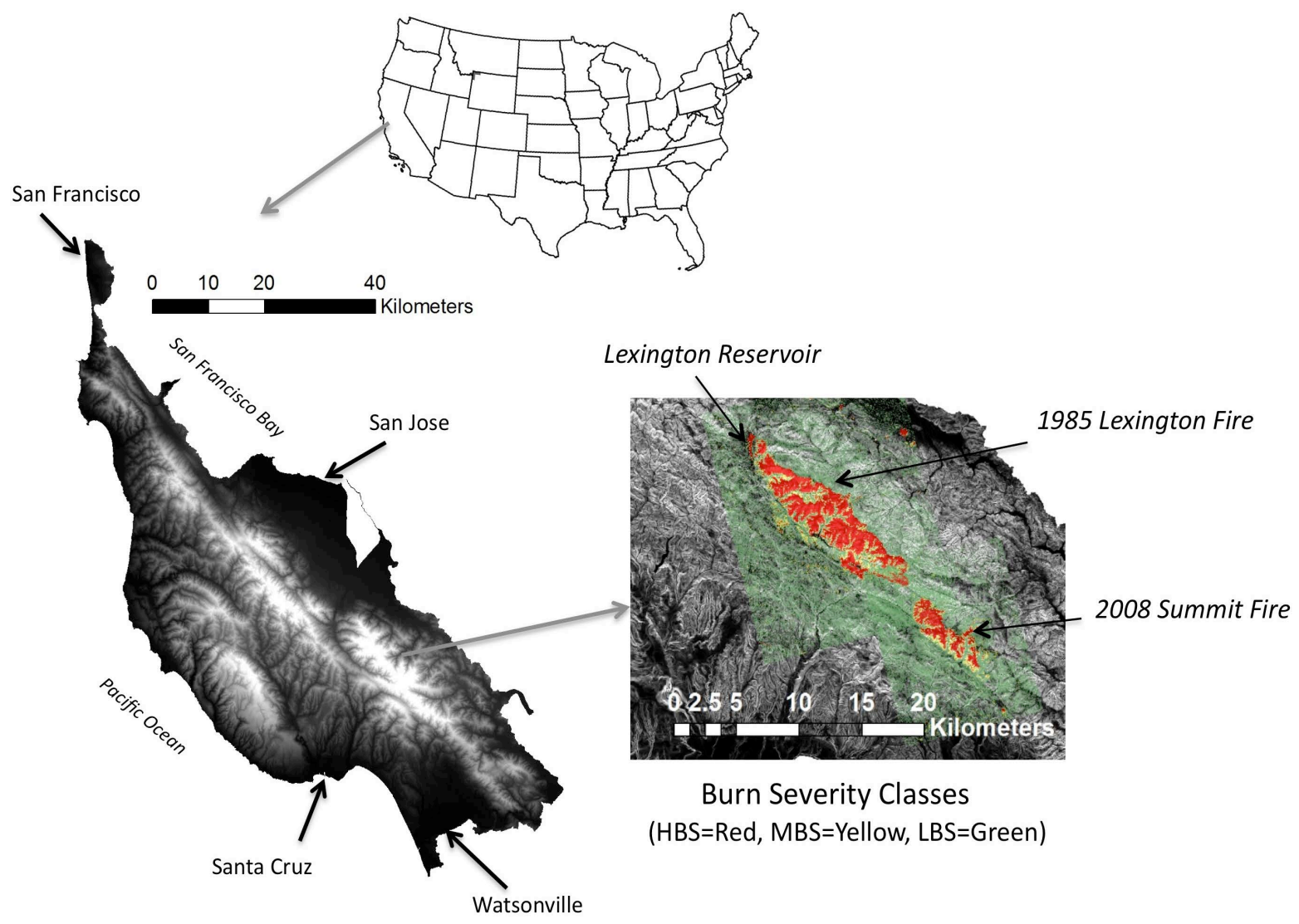

Elevation

Figure 1. Map of the Santa Cruz Mountain study area, with shaded elevation and burn severity classes for the Lexington and Summit Fires.

Remnant stands of old-growth forest are presently protected in state parks, most notably at Henry Cowell Redwoods, Portola Redwoods, and Big Basin State Park. Developed areas, used mostly for public recreation, cover roughly $25 \%$ of the study area, followed by grasslands (11\%) and shrublands (5\%) (Potter, 2015).

Climate in the area is Mediterranean, with historical monthly air temperatures ranging from averages of $7.8^{\circ} \mathrm{C}$ in January to $18.4^{\circ} \mathrm{C}$ in July (from Ben Lemond station, CA, National Weather Service Cooperative Network, $37.083^{\circ} \mathrm{N}, 122.100^{\circ} \mathrm{W}$, available at www.wrcc.dri.edu). The majority of precipitation falls between November and April, with an average of $98 \mathrm{~cm}$ per year (Black Mountain and Ben Lemond stations, CA, National Weather Service Cooperative Network). Snow may occur on the highest elevation ridge tops. Over the past several decades of climate records, extreme dry years were identified as having occurred in 1989-1991, 1994, 2007, and 2013 to 2015, and extreme wet years in 1983, 1996, and 2005 (Potter, 2015).

According to historical reports, the 5310 ha Lexington Fire of July 1985 spread primarily through chaparral patches and in ground fuels in the Los Gatos Creek drainage (Seaber et al., 1987), and resulted in 43\% high burn severity coverage (Montague, 2006). The principal carrier of the fire was the large tracts of native shrubland and broken tree tops from a prior year of heavy snow lying beneath mature tree stands. Potter (2015) reported that green vegetation cover had regrown by the year 2013 over about 4110 ha of the Lexington Fire perimeter, mainly north of Los Gatos Creek and east of the Lexington Reservoir (Figure 1).

The 1728 ha Summit Fire of May 2008 (Figure 1), half of which burned in the Corralitos Creek drainage (Seaber et al., 1987), resulted in 25\% high burn severity coverage (SEAT, 2008). The fire initially spread through shrubland on Loma Chiquita Ridge before being carried into heavily forested stands (CDFFP, 2009) in the Soquel Creek watershed. Areas of greatest vegetation damage within the Summit Fire perimeter were identified mainly along ridge tops in dense stands of knob cone pine (Potter, 2015). 


\section{Methods}

\subsection{Image Processing}

Imagery from the Landsat sensors 5 and 8 was selected between the years 1985 to 2015 from the US Geological Survey Earth Explorer data portal (http://earthexplorer.usgs.gov/). Image data from path/row 44/34 were consistently acquired for an anniversary window between June 1 and July 31 each year, around the peak of the growing season in the study area (Potter, 2012, 2014b) to minimize variation caused by seasonal sun angle differences.

All images used in this study acquired by Landsat sensors were geometrically registered using terrain correction algorithms (Storey, 2011) applied by the U. S. Geological Survey EROS Data Center. The Landsat Surface Reflectance Climate Data Record (CDR; Masek et al., 2006) applied corrections to the images used for top of atmosphere (TOA) reflectance, brightness temperature, and generated masks for clouds, cloud shadows, adjacent clouds, and surface water bodies. Cloud-filtered Landsat NDVI data sets from 1985 to 2015 were processed for time-series comparisons.

NDVI (scaled from 0 to 10,000) was computed for all Landsat images as the differential reflectance between the red and near-infrared (NIR) portions of the spectrum by the equation:

$$
\mathrm{NDVI}=(\mathrm{NIR}-\mathrm{Red}) /(\mathrm{NIR}+\mathrm{Red})
$$

where NIR is the reflectance of wavelengths from 0.76 to $0.9 \mu \mathrm{m}$ and Red is the reflectance from 0.63 to 0.69 $\mu \mathrm{m}$. Advantages of NDVI for the purpose of vegetation monitoring have been cited in its mathematical simplicity and ease of comparability across numerous multi-spectral remote sensing platforms (Lentile et al., 2006). Low values of NDVI (near 0) indicate barren land cover whereas high values of NDVI (near 8000) indicate dense canopy vegetation cover.

\subsection{Spatial Layers}

Elevation at 1 arc-second resolution was derived from the United States Geological Survey (USGS) National Elevation Dataset (NED). Slope (in percent) was calculated as the maximum rate of change in elevation value from that cell to its neighbors to determine the steepest downhill descent from the cell. Aspect was calculated by fitting a plane to the z-values of a $3 \times 3$ cell neighborhood around each 30-m cell (Burrough \& McDonell, 1998). The direction that the plane faces was set as the aspect for the cell. Aspect was expressed in degrees, moving clockwise from $0^{\circ}$ (due north) to $360^{\circ}$ (again to due north).

Vegetation cover types within the study area were determined from the USDA National Agricultural Statistics Service (NASS), California Cropland Data Layer (CDL) from 2014 (available at http://nassgeodata.gmu.edu/CropScape). The CDL is a raster, geo-referenced, crop-specific land cover data layer with a ground resolution of $30 \mathrm{~m}$ (Han et al., 2012). The CDL is produced using satellite imagery from the Landsat sensor collected during the growing season. Additional land cover mapping was used for summarizing NDVI analysis results, including the United States Geological Survey's National Land Cover Database (NLCD) from 2006.

Aboveground biomass (AGB) estimated for the year 2007 for all forest and woodland 30-m pixels areas was obtained from the mapping products of Zhang et al. (2014), who used a parametric model that combined high-resolution estimates of leaf area index (LAI) from the Landsat sensor with estimates of canopy maximum height from the Geoscience Laser Altimeter System (GLAS) sensor onboard ICESat, the Ice, Cloud, and land Elevation Satellite. Accuracy assessment tests showed that, at an aggregated scale, these AGB estimates from Landsat and GLAS were comparable to ground inventory-based estimates and previous satellite-based estimates.

Areas burned by wildfire were delineated from the database compiled by the California Department of Forestry, Fire and Resource Assessment Program (FRAP), with contributions from the USDA Forest Service, the Bureau of Land Management, and the National Park Service (data available at http://frap.cdf.ca.gov/). Burn severity classes at 30-m resolution for the 1985 Lexington Fire and the 2008 Summit Fire were determined by the Monitoring Trends in Burn Severity (MTBS) project, which has consistently mapped the burn severity classes and perimeters of fires greater than 405 ha (1000 acres) across the United States from 1984 to the present (Eidenshenk et al., 2007). MTBS is conducted through a partnership between the U.S. Geological Survey (USGS) National Center for Earth Resources Observation and Science (EROS) and the USDA Forest Service 
Remote Sensing Applications Center (RSAC).

Following the composite burn index (CBI) methodology, three burn severity (BS) classes were defined for forest types of California by Miller et al. (2009), namely low, moderate, and high BS. As the basis for the CBI protocol, fire effects were derived from ocular estimates in five vertical vegetation strata: 1) surface fuels and soils; 2) herbs, low shrubs and trees less than $1 \mathrm{~m}$ tall; 3) shrubs and trees 1 to $5 \mathrm{~m}$ tall; 4) intermediate trees; and 5) large trees. Following the CBI protocol, the low severity class was generally associated with little detectable change in any vegetation cover strata, whereas the high severity class was generally associated with complete mortality of live vegetation strata, i.e. stand replacing fire. The moderate BS class is a composite of high and low severity fire effects where neither clearly dominates. Moderate severity effects are often mapped as narrow transition bands surrounding contiguous patches of high severity effects.

\subsection{Statistical Analysis}

Tests of statistical significance were carried out using the two-sample Kolmogorov-Smirnov (K-S) test, a nonparametric method that compares the cumulative distributions of two data sets (Lehmann, 2006). The K-S test does not assume that data were sampled from Gaussian distributions (nor any other defined distributions), nor can its results be affected by changing data ranks or by numerical (e.g., logarithm) transformations. The K-S test reports the maximum difference between the two cumulative distributions, and calculates a $p$ value from that difference and the group sample sizes. It tests the null hypothesis that both groups were sampled from populations with identical distributions according to different medians, variances, or outliers. If the K-S $p$ value is small (i.e., <0.05), it can be concluded that the two groups were sampled from populations with significantly different distributions. Within the three separate BS classes (low, moderate, and high) of the fire areas, 2000 point locations were randomly selected to test the differences between cumulative distributions of NDVI change, AGB, elevation, slope, and aspect. A significant difference from zero, or between two (yearly) sample means of NDVI or other topographic variables at $95 \%$ confidence $(p<0.05)$, was based on the finding of a separation of the mean(s) at greater than (plus or minus) 2 standard errors (SE; Gelman \& Hill, 2007).

\section{Results}

\subsection{Topography and Vegetation Cover within Burn Severity Classes}

For the 1985 Lexington Fire and the 2008 Summit Fire, both elevation and aspect varied significantly (at $p<$ 0.05) among burn severity classes (Table 1 and Table 2). Average low burn severity (LBS) class elevation was lower than moderate burn severity (MBS) class elevation and high burn severity (HBS) class elevation by between $50 \mathrm{~m}$ and $250 \mathrm{~m}$. Average LBS aspect was lower than MBS and HBS aspect by between 20 and 35 degrees, which represented a transition from predominantly southeastern-facing hill slopes in LBS areas to predominantly southwestern-facing hill slopes within HBS areas. Average LBS class slope was lower than HBS class slope by about $3 \%$ in the Lexington fire burned areas. Average percent slope did not vary significantly among burn severity class for the Summit Fire burned areas.

Nonetheless, a comparison of frequency distributions for percent slope classes between the respective HBS areas of the two fires showed that the Lexington Fire had notably fewer HBS points in the lowest slope class $(0 \%-9 \%)$ and many more points in the highest slope class $(\geq 30 \%)$ compared to the Summit Fire HBS areas (Figure 2). The Summit Fire had significantly more (K-S test $p<0.01$ ) HBS points in the flatter slope classes of less than 20\%, which confirmed numerous first-hand ground observations that a high percentage of stream banks and creek-side forest stands were burned at high severity in the Summit Fire compared to the Lexington Fire (as seen in Photos 1-6). Likewise, the Summit Fire had only about 6\% of HBS points in the highest slope class, whereas the Lexington Fire had $18 \%$ of HBS points in the highest slope class.

The distribution of vegetation cover classes in the year 2006 across the randomly sampled points within the Lexington Fire area indicated that LBS and MBS classes were predominantly evergreen forest at $>40 \%$ cover, followed by mixed deciduous forest at $>20 \%$ cover (Figure 3 ). The same distribution of vegetation cover classes was detected in the year 2014 within LBS and MBS classes of the Lexington Fire, suggesting that the two land cover mapping methods (NLCD and CDL) were consistent and comparable over the eight-year interval between 2006 to 2014. Nevertheless, the change in HBS vegetation cover types at 20 - 30 years post-fire was different from all other areas burned in the Lexington Fire, with a relatively high percentage cover of shrubs in both 2006 
Table 1. Mean and 2 SE for topographic variables ( $N=2000$ points per burn class) and woody AGB $(N>1200$ points $)$ circa 2007 sampled within the 1985 Lexington Fire burn severity classes.

\begin{tabular}{|c|c|c|c|c|}
\hline Burn Severity Class & Elevation (m) & $\begin{array}{c}\text { Slope } \\
(\%)\end{array}$ & $\begin{array}{c}\text { Aspect } \\
\text { (degrees) }\end{array}$ & $\begin{array}{c}\text { AGB } 2007 \\
\text { (Mg/ha) }\end{array}$ \\
\hline \multirow[t]{2}{*}{ No Burn } & 388 & 17 & 158 & 236 \\
\hline & 10 & $<1$ & 5 & 3 \\
\hline \multirow[t]{2}{*}{ Low (LBS) } & 447 & 18 & 172 & 245 \\
\hline & 10 & $<1$ & 5 & 2 \\
\hline \multirow[t]{2}{*}{ Moderate (MSB) } & 515 & 19 & 190 & 227 \\
\hline & 11 & $<1$ & 5 & 2 \\
\hline \multirow[t]{2}{*}{ High (HBS) } & 665 & 22 & 205 & 207 \\
\hline & 10 & $<1$ & 4 & 2 \\
\hline
\end{tabular}

Table 2. Mean and 2 SE for topographic variables $(N=2000$ points per burn class) and woody AGB $(N>1200$ points per burn class) circa 2007 sampled within the 2008 Summit Fire burn severity classes.

\begin{tabular}{|c|c|c|c|c|}
\hline Burn Severity Class & Elevation (m) & $\begin{array}{l}\text { Slope } \\
(\%)\end{array}$ & $\begin{array}{c}\text { Aspect } \\
\text { (degrees) }\end{array}$ & $\begin{array}{c}\text { AGB } 2007 \\
\text { Pre-fire (Mg/ha) }\end{array}$ \\
\hline \multirow[t]{2}{*}{ No Burn } & 455 & 18 & 172 & 200 \\
\hline & 9 & $<1$ & 4 & 3 \\
\hline \multirow[t]{2}{*}{ Low (LBS) } & 464 & 19 & 164 & 231 \\
\hline & 9 & $<1$ & 5 & 2 \\
\hline \multirow[t]{2}{*}{ Moderate (MSB) } & 588 & 19 & 199 & 192 \\
\hline & 9 & $<1$ & 4 & 3 \\
\hline \multirow[t]{2}{*}{ High (HBS) } & 730 & 19 & 203 & 171 \\
\hline & 6 & $<1$ & 3 & 2 \\
\hline
\end{tabular}

(at $>25 \%$ cover) and in 2014 (at $>15 \%$ cover), mainly at the expense of evergreen tree cover.

For the 2008 Summit Fire area, the distribution of vegetation cover types sampled in 2006 (pre-fire) and again in 2014 (post-fire) indicated that the LBS class vegetation remained constant, with predominantly evergreen forest at $>65 \%$ cover, followed by mixed deciduous forest at $>15 \%$ cover (Figure 3 ). The Summit fire MBS class was also largely unchanged in vegetation type distribution following the 2008 fire, with evergreen forest, mixed deciduous forest, and shrub cover remaining nearly equal to pre-fire levels at slightly over $20 \%$ each. However, vegetation cover types in HBS areas of the Summit Fire changed markedly following the 2008 fire, with an increased percentage cover of shrubs from $33 \%$ pre-fire to $46 \%$ post-fire. This increase in shrub cover was mainly at the expense of evergreen tree cover within the Summit fire HBS area, which declined from 31\% cover pre-fire to $8 \%$ cover post-fire.

\subsection{Trends in NDVI}

Average NDVI in 1984 (the year before the Lexington Fire) did not differ significantly among the MBS area, the HBS area, and the "No burn" buffer area (just outside the fire perimeter) making up the burned Lexington Fire landscape by the end of the summer of 1985 (Figure 4(a)). The LBS average NDVI sampled in 1984 was slightly higher (300 NDVI units) than the other pre-fire BS class average NDVI values in 1984.

Post-fire NDVI levels in 1985 decreased significantly $(p<0.01)$ within MBS and HBS areas of the Lexington Fire, to 76\% (MBS) and 42\%, (HBS) of pre-fire 1984 NDVI values, whereas the post-fire LBS average NDVI did not change significantly from 1984 to 1985. In the following years, rapid regeneration of NDVI was observed for the Lexington Fire MBS and HBS areas, with average NDVI recovering to within $95 \%$ of 1984 pre-fire average NDVI values by 1989 for both of these BS classes. From 1990 to 1996, average NDVI in all BS 


\section{Lexington Fire}

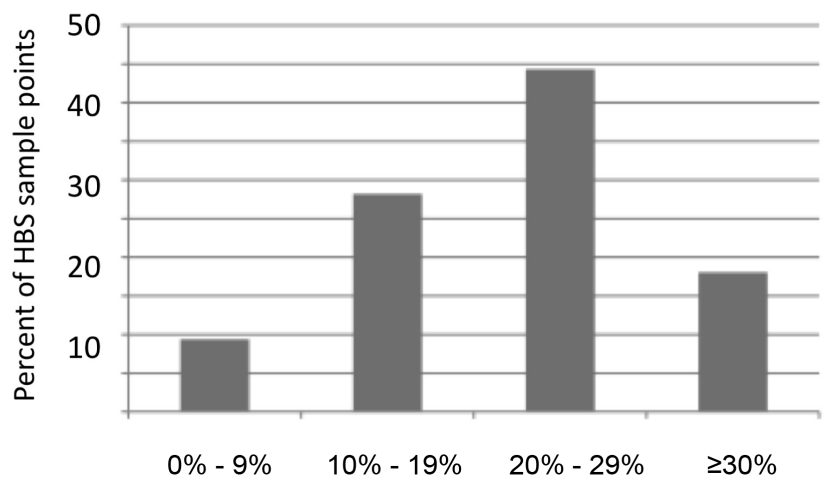

Summit Fire

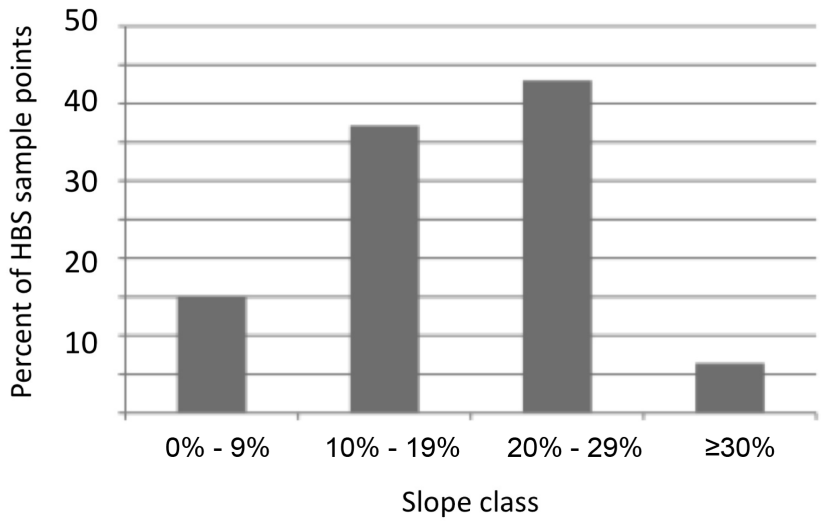

Figure 2. Slope class distribution for HBS areas $(N=2000$ per fire $)$ of the Lexington and Summit Fires.

\section{Lexington Fire}

2006

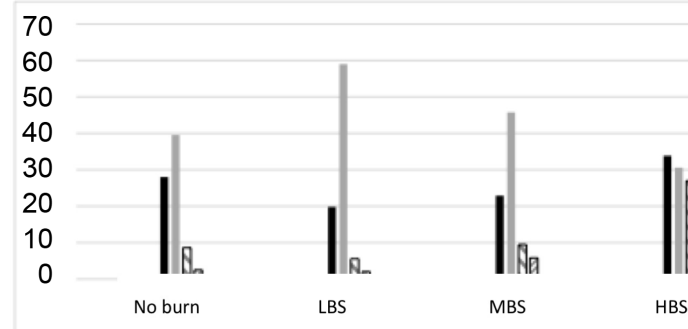

- 2006 D. Forest $=2006$ E. Forest $\quad 2006$ Shrub घ2006 Grass

2014

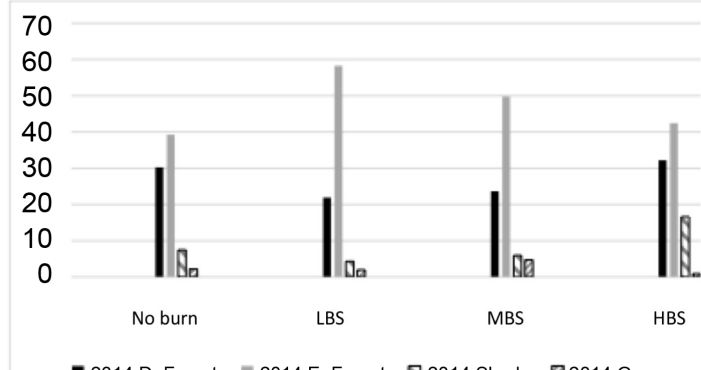

Figure 3. Land cover class distributions sampled within the Lexington Fire and Summit Fire burn severity classes $(N=2000$ points per burn class).
Summit Fire
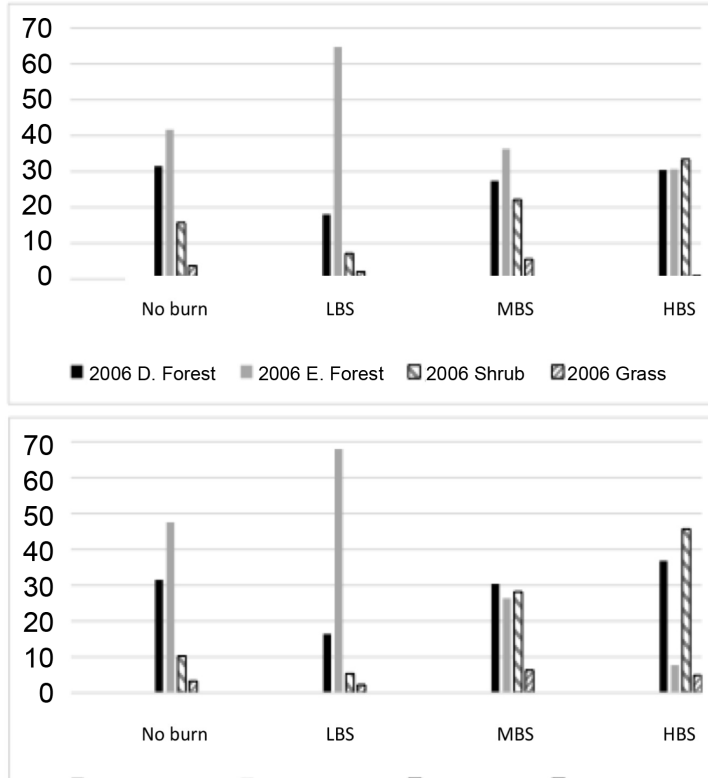

- 2014 D. Forest $=2014$ E. Forest $\nabla_{2014}$ Shrub $\square 2014$ Grass 


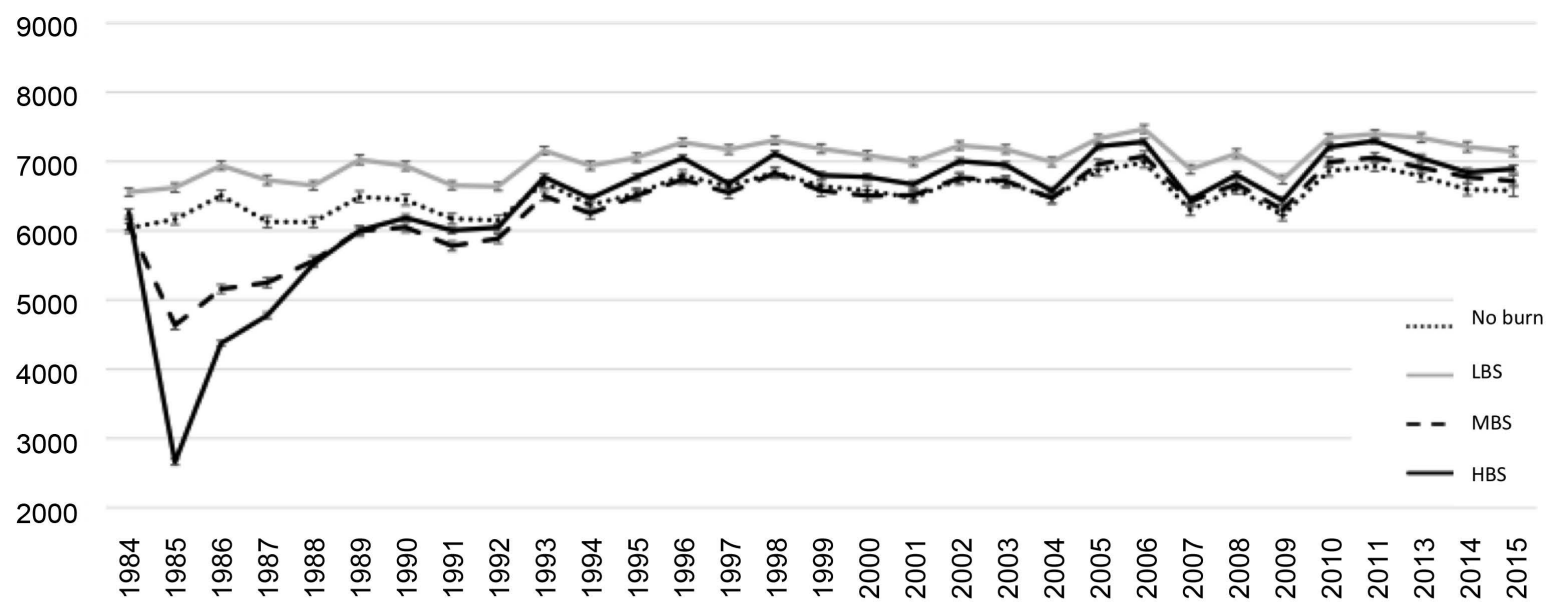

(a)

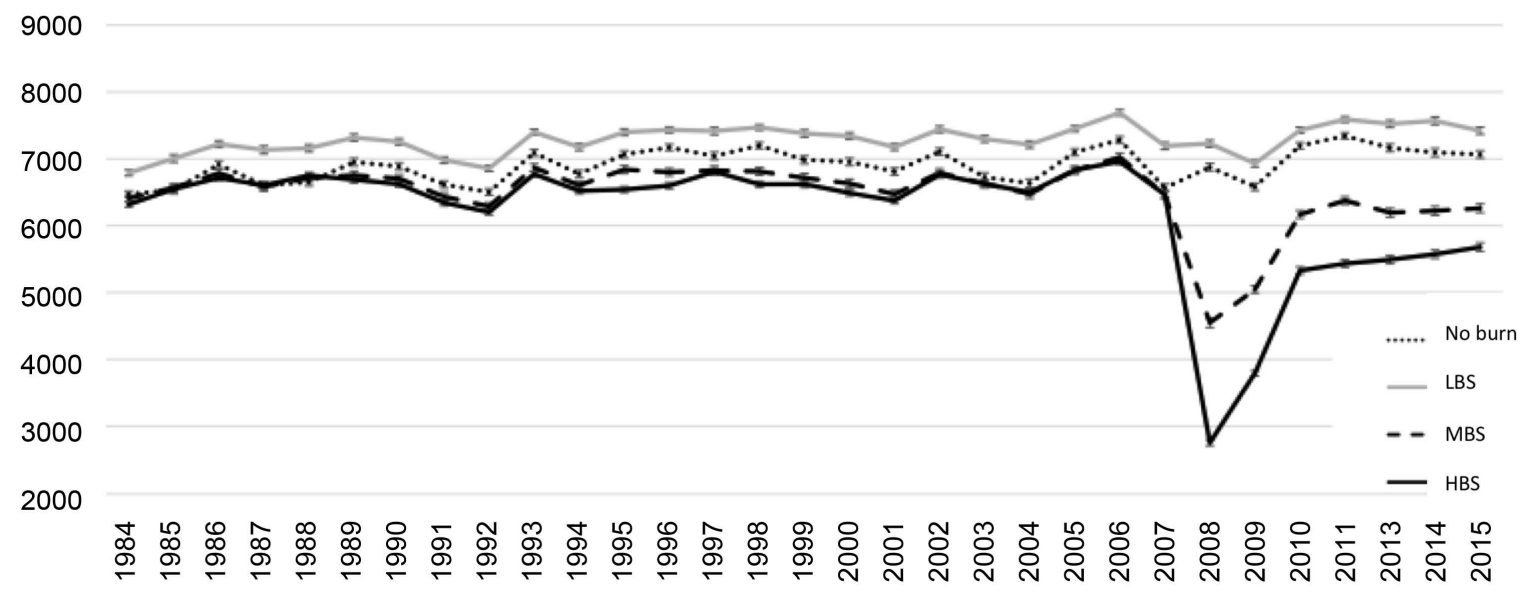

(b)

Figure 4. Landsat NDVI time series from 1984 to 2015 for burn severity classes within the (a) Lexington Fire and (b) Summit Fire for $(N=2000$ points sampled per burn class). Error bars represent plus or minus 2 SE of the yearly mean NDVI.

classes of the Lexington Fire area increased slowly to match or exceed 1984 pre-fire average NDVI values. From 1997 to 2015, average NDVI in all BS classes of the Lexington Fire area was relatively constant, varying by only \pm 300 NDVI units (or by about $\pm 4 \%$ of the mean NDVI from 1997). Years during which NDVI decreased temporarily by about $-4 \%$ were 1999, 2007, and 2014-15. These were among the lowest rainfall years in the past two decades in the Santa Cruz Mountains (Potter, 2015).

Average NDVI in HBS areas of the Lexington Fire was shown to be significantly higher $(p<0.05)$ than average NDVI in MBS areas during relatively wet precipitation years, namely 1995, 2005 and 2010. In nearly all years since 1984, average NDVI in LBS areas of the Lexington Fire and the Summit Fire has been significantly higher $(p<0.05)$ than average NDVI in any other BS class from either fire.

From 1985 to 2007, average NDVI in all BS classes of the Summit Fire area was relatively constant, varying by only \pm 300 NDVI units, or by about $\pm 5 \%$ of the mean NDVI from 2007 (Figure 4(b)). NDVI decreased by $-5 \%$ temporarily during 1991-1992, which were among the lowest rainfall years during the past three decades in the Santa Cruz Mountains (Potter, 2015).

Post-fire NDVI levels in 2009 decreased significantly $(p<0.01)$ within MBS and HBS areas of the Summit Fire, to 70\% (MBS) and 43\%, (HBS) of pre-fire 2007 NDVI values, whereas the post-fire LBS average NDVI did not change significantly from 2007 to 2008. This pattern of NDVI change from 2007 to 2008 across all three Summit Fire BS classes was nearly identical to the immediate effects of the 1985 Lexington Fire on NDVI. 


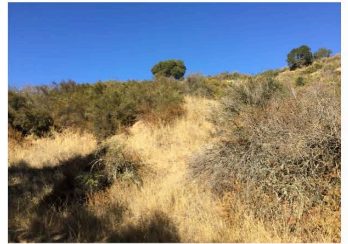

1. HBS with shrubs

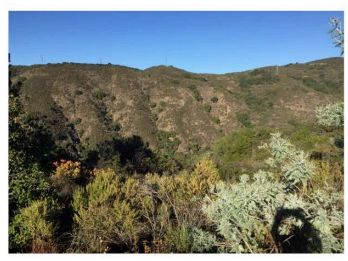

3. HBS hillslope

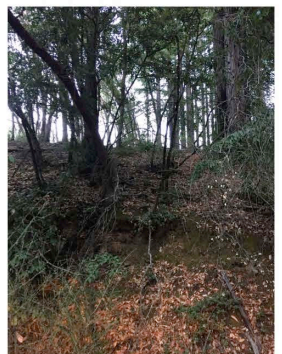

5. HBS hillslope

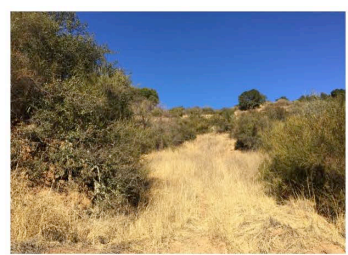

2. HBS with live oak and shrubs

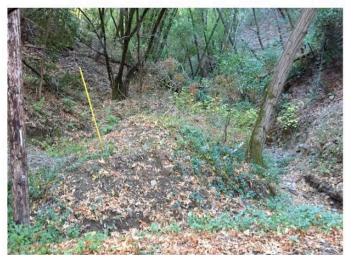

4. MBS streamside

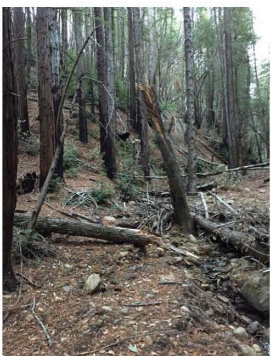

6. HBS streamside

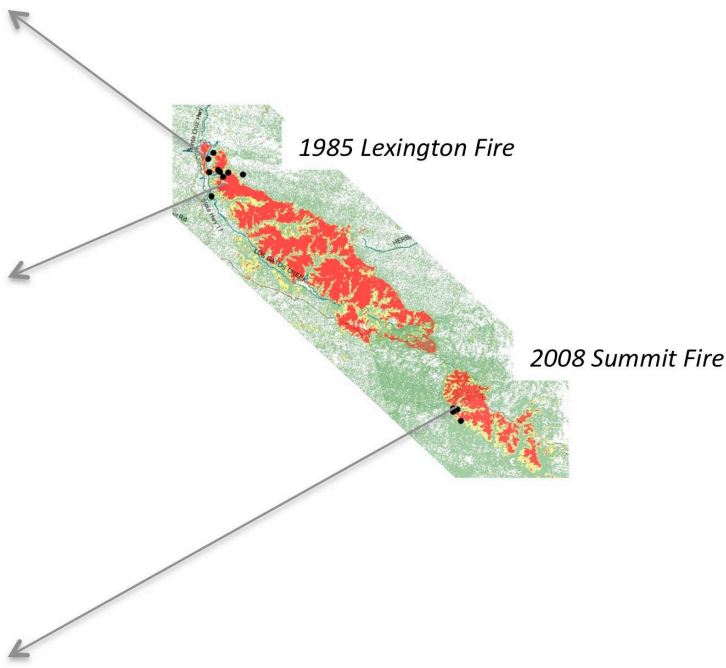

Photo 1-6. Photos for locations shown in black dot symbols in the burned area map (HBS = Red, MBS = Yellow, LBS = Green) at right.

However, in the years following the Summit Fire, regeneration of NDVI was slower (compared to the rate observed for the Lexington Fire) for the Summit Fire HBS areas, with average NDVI recovering to only about 88\% of 2007 pre-fire average NDVI values by 2015. In 2015, mean NDVI for the MBS areas of the Summit Fire was still about $4 \%$ lower than 2007 pre-fire average NDVI values, whereas mean NDVI for the LBS areas of the Summit Fire was 3\% higher than 2007 pre-fire average NDVI values.

\subsection{Regrowth of Aboveground Biomass from the Lexington Fire}

Live AGB in wooded areas of the Lexington Fire was significantly higher (K-S test $p<0.01$ ) at 20 years post-fire within the LBS (or within the MBS) area compared to AGB in the HBS area of the Lexington Fire (Table 1). Although AGB in the HBS area was not significantly correlated with either slope or elevation, it was, on average, $30 \mathrm{Mg} \cdot \mathrm{ha}^{-1}$ lower than AGB in the LBS area of the Lexington Fire.

Pre-fire AGB of the Summit Fire coverage was also $30-60 \mathrm{Mg} \cdot \mathrm{ha}^{-1}$ lower (K-S test $p<0.01$ ) within what would become the HBS area in 2008, compared to unburned areas and within what would become the LBS area in 2008 of the Summit Fire (Table 2). Pre-fire AGB of the Summit Fire areas ranged widely from 86 to 412 $\mathrm{Mg} \cdot \mathrm{ha}^{-1}$, but was not significantly correlated $(p<0.1)$ with either slope or elevation across the entire 2008 burned area.

\section{Discussion}

The results of this study, derived from more than 30 years of Landsat image analysis, support the conclusion that repeated drought periods have not slowed forest and shrub regrowth rates within the 1985 Lexington Fire area. In all burned areas of the Lexington Fire, NDVI recovered within five years to 95\% of pre-fire average NDVI values. In contrast, within HBS areas of the 2008 Summit Fire, average NDVI at seven years post-fire has recovered to about $88 \%$ of pre-fire average NDVI values. 
An explanation for this difference in post-fire recovery rates of NDVI between the Lexington and Summit Fires can be inferred from the topography of burned areas and from photographic evidence of 2015 vegetation cover in different burned areas (Photos 1-6). The Lexington Fire had a small fraction of HBS area (less than $10 \%)$ in the lowest slope classes $(0 \%-9 \%)$ and a greater fraction (more than $60 \%$ HBS area) in the highest slope classes $(\geq 20 \%)$, compared to the Summit Fire HBS areas. This distribution of HBS area would have started to regrow from bare, charred ground or from formerly forested stands with no living trees. On HBS hill slopes of the Lexington Fire, photographs from 2015 showed that vegetation communities were dominated by a mix of thick shrub cover and small (2 - 3 m high) live oak trees (Quercus agrifolia), on steep slopes, but with practically no bare soil exposed (Photos 1-3). In contrast, on the flatter HBS hill slopes of the Summit Fire, photographs from 2015 showed that vegetation communities were dominated by many standing dead, charred pine tree stems, with a sparse ground cover of small manzanita shrubs and oak sprouts on predominately exposed, bare soil (Photos 5-6).

Because many HBS areas of the Lexington Fire were located on steeper slopes than many of the HBS areas of the Summit Fire, the evergreen live oak and shrub cover that burned completely during the 1985 fire left behind relatively few large standing, charred tree stems (absent from Photos 1-2) to shade the regenerating vegetation cover, which consequently, could sprout directly from the bare ground and regrow with ample sunlight. In contrast, the many standing, charred tree stems left in the HBS areas of the Summit Fire have been shading flatter hill slopes (present in Photos 5-6), and evidently delaying sapling regrowth and stand thinning beneath their many down and decaying tree boles as well.

Similar patterns of post-fire vegetation regeneration were reported by Crotteau et al. (2013) for the 2000 Storrie Fire in the Lassen National Forest of northern California. The highest conifer regeneration densities were measured 10 years post-fire in LBS and MBS areas of the Storrie Fire, due to nearby remnant mature, seedbearing pine trees. In addition to seed production for new seedlings, the remnant overstory canopy in LBS and MBS areas produced high shade levels, which may have limited regrowth of shrubs, further permitting high densities of pine seedling establishment. In contrast, the HBS areas of the Storrie Fire showed sparse overstory tree survival, such that the distance to seed sources was presumed to be a limiting factor to pine seedling establishment. Consequently, shrubs covered $8 \%$ of LBS areas $17 \%$ of MBS areas and 53\% of HBS areas 10 years after the fire.

The gradual increase over the past 30 years in forest and shrubland canopy cover (inferred from NDVI) in the LBS areas trends of both the 1985 Lexington and 2008 Summit fires suggest that drought periods have not slowed the accumulation of fire fuels in this portion of the Santa Cruz Mountains. Based on NDVI, there appeared to be more live green biomass in all areas of the Lexington Fire in 2015 compared to (pre-fire) 1984 biomass. This dense shrub cover with mixed oak trees on steep rugged hill sides puts all residential housing structures located throughout these mountain roads at equal or greater risk for damage from wildfires as was seen in the 1980s.

The Summit Fire burned over a sizable portion of the headwaters of Corralitos Creek (Potter, 2015), a tributary of the Pajaro River (PVWMA, 2002) that is important steelhead trout habitat and also serves as a drinking water supply for the City of Watsonville (population 52,470 in 2013). Much of the land within the upper Corralitos Creek drainage basin is zoned for timber production, and a number of landowners have prepared non-industrial timber management plans to facilitate on-going harvest operations (Land Trust of Santa Cruz County, 2011). Moreover, county reports state that development of rural residential dwellings is progressing in the Santa Cruz Mountains at a moderate to rapid pace (CalFire, 2014). Where there were once scattered rural summer cabins on winding, narrow roads, there are now year-round residential subdivisions on steep paved roads, and an increased density of large estate structures. In 2008 alone, over 75 structures in WUI zones were destroyed by wildfires in Santa Cruz County (CDFFP, 2009).

\section{Conclusion}

Landsat satellite image time-series analysis since 1984 was conducted within the Los Gatos Creek and Corralitos Creek watersheds in the Santa Cruz Mountains. Results showed that the several severe drought periods recorded since the 1980s in California have not inhibited rapid tree and shrub regrowth rates on steep hill slopes burned recently by wildfires in the study area. In HBS areas of both the Lexington and Summit fires, post-fire vegetation types showed a marked increase in dense shrub cover, mainly at the expense of evergreen tree cover. 
Exposed south-facing slopes are typically supporting 200 to $240 \mathrm{Mg} \cdot \mathrm{ha}^{-1}$ of low $(<3 \mathrm{~m})$ standing woody biomass that can regenerate in as little as five years from charred ground. This study is the first of its kind to utilize the full 30-year record of Landsat vegetation index data, together with satellite image products from a Laser Altimeter sensor, to monitor tree and shrub regrowth after stand-replacing wildfires in California.

\section{References}

Bakker, E. (1984). An Island Called California (Chapters 4, 5, 6). Berkeley, CA: University of California Press.

Baret, F., Olioso, A., Luciani, J. L., and Hanocq, J. F. (1989). Estimation de l'energie photosynthetiquement active absorbee par une culture de ble’ a` partir de donnees radiometriques. Agronomie, 9, 885-895. http://dx.doi.org/10.1051/agro:19890906

Burrough, P. A., \& McDonell, R. A. (1998). Principles of Geographical Information Systems (190 p). New York: Oxford University Press.

California Department of Forestry and Fire Protection (CDFFP) (2009). Lockheed Fire Post-Fire Risk Assessment (108 p). San Mateo-Santa Cruz Unit.

CalFire (2014). Santa Cruz County-San Mateo County, Community Wildfire Protection Plan, California Department of Forestry and Fire Protection (CDF), Santa Cruz, CA, 36 p.

Casady, G. M., \& Marsh, S. E. (2010). Broad-Scale Environmental Conditions Responsible for Post-Fire Vegetation Dynamics. Remote Sensing, 2, 2643-2664. http://dx.doi.org/10.3390/rs2122643

Collins, J. B., \& Woodcock, C. E. (1996). An Assessment of Several Linear Change Detection Techniques for Mapping Forest Mortality Using Multi-Temporal Landsat TM Data. Remote Sensing of Environment, 56, 66-77. http://dx.doi.org/10.1016/0034-4257(95)00233-2

Crotteau, J. S., Varner III, J. M., \& Ritchie, M. W. (2013). Post-Fire Regeneration across a Fire Severity Gradient in the Southern Cascades. Forest Ecology and Management, 287, 103-112. http://dx.doi.org/10.1016/j.foreco.2012.09.022

County of Santa Cruz (2013). Climate Action Strategy, 5.0 Vulnerability Assessment (81 p). Santa Cruz, CA: Department of Planning.

Cuevas-Gonzalez, M., Gerard, F., Balzter, H., \& Riano, D. (2009). Analysing Forest Recovery after Wildfire Disturbance in Boreal Siberia Using Remotely Sensed Vegetation Indices. Global Change Biology, 15, 561-577. http://dx.doi.org/10.1111/j.1365-2486.2008.01784.x

Dennison, P. E., Brewer, S. C., Arnold, J. D., \& Moritz, M. A. (2014). Large Wildfire Trends in the Western United States, 1984-2011. Geophysical Research Letters, 41, 2928-2933.

Epting, J., \& Verbyla, D. L. (2005). Landscape Level Interactions of Pre-Fire Vegetation, Burn Severity, and Post-Fire Vegetation over a 16-Year Period in Interior Alaska. Canadian Journal of Forest Research, 35, 1367-1377.

Eidenshenk, J., Schwind, B., Brewer, K., Zhu, Z., Quayle, B., \& Howard, S. (2007). A Project for Monitoring Trends in Burn Severity. Fire Ecology Special Issue, 3, 3-21. http://dx.doi.org/10.4996/fireecology.0301003

Fischer, L., Rosenberg, M., Mahon, L., Liu, Z., Maurizi, B., Longmire, P., \& Shupe, S. (2004). Monitoring Land Cover Changes in California, a USFS and CDF Cooperative Program, Northern Sierra Project Area-Cycle II. Sacramento, CA: State of California, Resources Agency, Department of Forestry and Fire Protection.

Flint, L. E., \& Flint, A. L. (2012). Simulation of Climate Change in San Francisco Bay Basins, California: Case Studies in the Russian River Valley and Santa Cruz Mountains (55 p). US Geological Survey Scientific Investigations Report 2012-5132.

Gelman, A., \& Hill, J. (2007). Data Analysis Using Regression and Multilevel/Hierarchical Models. New York: Cambridge University Press.

Gitas, I., Mitri, G., Veraverbeke, S., \& Polychronaki, A. (2012). Advances in Remote Sensing of Post-Fire Vegetation Recovery Monitoring-A Review. In L. Fatoyinbo (Ed.), Remote Sensing of Biomass: Principles and Applications (pp. 143-176). Rijeka: INTECH.

Goulden, M. L., \& Bales, R. C. (2014). Mountain Runoff Vulnerability to Increased Evapotranspiration with Vegetation Expansion. Proceedings of the National Academy of Sciences of the United States of America, 111, 14071-14075.

Han, W., Yang, Z., Di, L., \& Mueller, R. (2012). Crop Scape: A Web Service Based Application for Exploring and Disseminating US Conterminous Geospatial Cropland Data Products for Decision Support. Computers and Electronics in Agriculture, 84, 111-123. http://dx.doi.org/10.1016/j.compag.2012.03.005

Headwaters Economics (2008). Headwaters Economics 2008 Study. http://www.headwaterseconomics.org/wildfire/

Land Trust of Santa Cruz County (2011). A Conservation Blueprint: Assessment and Recommendations, 80 p. http://www.landtrustsantacruz.org/blueprint 
Lehmann, E. (2006). Nonparametrics: Statistical Methods Based on Ranks (464 p). New York: Springer.

Lentile, L., Holden, A., Smith, A., Falkowski, M., Hudak, A., \& Morgan, P. (2006). Remote Sensing Techniques to Assess Active Fire Characteristics and Post-Fire Effects. International Journal of Wildland Fire, 15, 319-345. http://dx.doi.org/10.1071/WF05097

Masek, J. G., Vermote, E. F., Saleous, N., Wolfe, R., Hall, F. G., Huemmrich, F., Gao, F., Kutler, J., \& Lim, T. K. (2006). A Landsat Surface Reflectance Data Set for North America, 1990-2000. Geoscience and Remote Sensing Letters, 3, 68-72. http://dx.doi.org/10.1109/LGRS.2005.857030

McMichael, C. E., Hope, A. S., Roberts, D. A., \& Anaya, M. R. (2004). Post-Fire Recovery of Leaf Area Index in California Chaparral: A Remote Sensing Chronosequence Approach. International Journal of Remote Sensing, 25, 4743-4760. http://dx.doi.org/10.1080/01431160410001726067

Miller, J. D., Knapp, E. E., Key, C. H., Skinner, C. N., Isbell, C. J., Creasy, R. M., \& Sherlock, J. W. (2009). Calibration and Validation of the Relative Differenced Normalized Burn Ratio (RdNBR) to Three Measures of Fire Severity in the Sierra Nevada and Klamath Mountains, California, USA. Remote Sensing of Environment, 113, 645-656. http://dx.doi.org/10.1016/j.rse.2008.11.009

Montague, R. E. (2006). Wildland Fire Analysis and Comments Based on the San Jose Water Company NTMP, November 7 , 2006.

Pajaro Valley Water Management Agency (PVWMA) (2002). PVWMA Basin Management Plan, Section 2: State of the Basin. Basin Management Plan Documents. http://www.pvwma.dst.ca.us/hydrology/basin-monitoring.php

Potter, C. S. (2012). Net Primary Production and Carbon Cycling in Coast Redwood Forests of Central California. Open Journal of Ecology, 2, 147-153.

Potter, C. S. (2014a). Ten Years of Forest Cover Change in the Sierra Nevada Detected Using Landsat Satellite Image Analysis. International Journal of Remote Sensing, 35, 7136-7153. http://dx.doi.org/10.1080/01431161.2014.968687

Potter, C. S. (2014b). Microclimate Influences on Vegetation Water Availability and Net Primary Production in Coastal Ecosystems of Central California. Landscape Ecology, 29, 677-687.

Potter, C. S. (2015). Thirty Years of Vegetation Change in the Coastal Santa Cruz Mountains of Northern California Detected Using Landsat Satellite Image Analysis. Journal of Coastal Conservation.

Rogan, J., \& Franklin, J. (2001). Mapping Wildfire Burn Severity in Southern California Forests and Shrublands Using Enhanced Thematic Mapper Imagery. Geocarto International, 16, 89-99.

Rogan, J., Miller, J., Stow, D. A., Franklin, J., Levien, L., \& Fischer, C. (2003). Land-Cover Change Monitoring with Classification Trees Using Landsat TM and Ancillary Data. Photogrammetric Engineering and Remote Sensing, 69, $793-804$. http://dx.doi.org/10.14358/PERS.69.7.793

Seaber, P. R., Kapinos, F. P., \& Knapp, G. L. (1987). Hydrologic Unit Maps. US Geological Survey Water-Supply Paper 2294, 63 p.

State Emergency Assessment Team (SEAT) (2008). Report on the Summit-Martin Fires. Santa Cruz and Santa Clara Counties, CA, $130 \mathrm{p}$.

Stephens, S. L., \& Fry, D. L. (2005). Fire History in Coast Redwood Stands in the Northeastern Santa Cruz Mountains, California. Fire Ecology, 1, 1-19. http://dx.doi.org/10.4996/fireecology.0101002

Storey, J. C. (2011). Landsat Image Geocorrection and Registration. In J. Le Moigne, N. S. Netanyahu, \& R. D. Eastman (Eds.), Image Registration for Remote Sensing (pp. 400-414). New York: Cambridge University Press. http://dx.doi.org/10.1017/cbo9780511777684.019

Thomas, J. H. (1961). Flora of the Santa Cruz Mountains of California: A Manual of the Vascular Plants (p. 5). Stanford, CA: Stanford University Press.

Westerling, A. L., Hidalgo, H. G., Cayan, D. R., \& Swetnam, T. W. (2006). Warming and Earlier Spring Increase Western US Forest Wildfire Activity. Science, 313, 940-943. http://dx.doi.org/10.1126/science.1128834

Zhang, G., Ganguly, S., Nemani, R. R., White, M. A., Milesi, C., Hashimoto, H., Wang, W., Saatchi, S., Yu, Y., \& Myneni, R. B. (2014). Estimation of Forest Aboveground Biomass in California Using Canopy Height and Leaf Area Index Estimated from Satellite Data. Remote Sensing of Environment, 151, 44-56. http://dx.doi.org/10.1016/j.rse.2014.01.025 